\title{
A COLUNA PRESTES E SEUS IMPACTOS NAS RELAÇÓES INTERNACIONAIS DO BRASIL
}

\section{THE COLUNA PRESTES (PRESTES' COLUMN) AND ITS IMPACTS ON BRAZIL'S INTERNATIONAL RELATIONSHIPS}

Mateus Fernandez Xavier ${ }^{1}$

\begin{abstract}
Resumo: O presente artigo tem como objetivo apontar as influências da Coluna Prestes sobre as relações internacionais do Brasil na década de 1920. Por meio da análise do contexto político, social, econômico e internacional do país, foi possível compreender as condicionalidades impostas à atuação externa brasileira. A apresentação da configuração do Exército Brasileiro e dos movimentos subversivos que tiveram origem no interior dessa instituição também forneceu elementos importantes para o estabelecimento da relação existente entre a Coluna Prestes e as medidas tomadas pelas chancelarias de Félix Pacheco e, em menor medida, de Otávio Mangabeira. Por meio da correlação de dados e informações levantados foi possível perceber como o Ministério das Relações Exteriores foi utilizado como instrumento de repressão a movimentos que contestaram a ordem oligárquica da República Velha.
\end{abstract}

Palavras-chave: Coluna Prestes; política externa brasileira; movimentos revolucionários; repressão; Ministério das Relações Exteriores; Argentina.

Summary: This article attempts to describe the influences that the 'Coluna Prestes' had on the Brazilian foreign policy during the 1920 decade. Analyzing the political, social, economic and international context of that period, it was possible to understand which limits of action affected Brazilian international movements. The description of the Brazilian Army configuration and the analysis of the insurgent revolutionary movements that were triggered by ideologies of this institution, furnish important information on the impacts of 'Coluna Prestes' over the chancelleries of Félix Pacheco and, to a lesser extent, of Otávio Mangabeira. Correlating all data obtained, it is possible to perceive how the Ministry of External Relations was used as an instrument of repression against the movements that opposed the oligarchic order of the República Velha.

Key-words: Coluna Prestes; Brazilian foreign policy; revolutionary uprisings; repression; Ministry of External Relations; Argentina.

1 Mestrado em Relações Internacionais pela Universidade de Brasília (2011), mestrado em Diplomacia pelo Instituto Rio Branco (2011), graduação em Ciências Sociais pela Universidade Federal de Minas Gerais (2006) e graduação em Relações Internacionais pela Pontifícia Universidade Católica de Minas Gerais (2004). Diplomata de carreira, trabalha atualmente em Brasília. 


\section{Introdução}

A constatação da existência de significativa lacuna nos estudos de política externa brasileira sobre a década de 1920 e o fato de o governo Artur Bernardes ter sido caracterizado por grande agitação interna chamam atenção para os anos compreendidos entre 1922 e 1926. Nesse período, há destaque para a Coluna Prestes como movimento importante no contexto de grande agitação ideológica dentro das Forças Armadas brasileiras, entre o período de 1900 e 1930. Considerando que a marcha revolucionária de Isidoro Dias Lopes, Miguel Costa, Luiz Carlos Prestes, Siqueira Campos, Cordeiro de Farias, Juarez Távora e João Alberto passou por regiões próximas à fronteira do Brasil com a Argentina, atravessou território paraguaio para ingressar no Mato Grosso e exilou-se na Bolívia, concluir que esse movimento produziu impactos internacionais parece ser plausível.

Para compreender os impactos sobre a política externa brasileira exercidos pela Coluna Prestes e pelos movimentos que Ihe originaram, é importante entender, previamente, a situação política, social e econômica do Brasil à época desses levantes revolucionários. A elucidação do contexto histórico da década de 1920 e das causas que deram origem à eclosão do movimento fornece suporte para compreender as principais ideologias que orientaram as Forças Armadas e os rebeldes da Coluna Prestes - já que muitos de seus comandantes eram militares além de estabelecer as diretrizes essenciais que pautaram a política externa brasileira no período em análise.

O presente artigo busca demonstrar como o movimento rebelde em questão causou repercussão principalmente na América do Sul. As missões diplomáticas do Brasil em Assunção, Buenos Aires, Montevidéu e La Paz mandavam informes, telegramas e outras correspondências diplomáticas em abundância, ao Rio de Janeiro, dando ciência ao governo federal de todos os passos dos jovens oficiais. De acordo com o planejamento dos rebeldes, a busca por víveres, suprimentos e armamentos nos países vizinhos era fundamental para a marcha, e o governo federal bem o sabia. Dessa maneira, durante o mandato de Artur Bernardes, a política externa brasileira para a região platina foi caracterizada por significativo esforço junto às nações vizinhas, para neutralizar o empreendimento logístico da 
Coluna e amenizar as más repercussões advindas do combate ao movimento.

\section{AS ORIGENS E O DESENVOLVIMENTO DA COLUNA PRESTES}

\section{O contexto doméstico e as ideologias em voga nas Forças Armadas.}

O período denominado pela historiografia brasileira de República Velha (1889 - 1930) foi configurado por anos de grande instabilidade política e social. Desde os governos militares de Deodoro da Fonseca (1889-91) e Floriano Peixoto (1891-94) até a Revolução de Trinta e a ascensão de Vargas ao poder, o país vivenciou diversas revoltas e sublevações de cunho militar, além de inúmeras contestações civis.

Nesse período, a sociedade brasileira tornou-se mais complexa. Os processos de urbanização e industrialização fizeram surgir uma classe operária nas maiores cidades da época, como, por exemplo, São Paulo e Rio de Janeiro, composta, em sua maioria, por imigrantes europeus ${ }^{2}$.

Outro setor advindo dos processos de industrialização e urbanização foram as camadas médias urbanas. Esse conjunto de agentes nunca teve grande coesão em suas ações, pelo fato de ser composto por grupos cujos interesses eram diversos. Desse modo, filhos de famílias proprietárias decadentes, profissionais liberais, pequenos proprietários de fábricas, comerciantes, funcionários públicos e intelectuais compunham o crescente setor médio da sociedade e passaram a reivindicar maior participação na vida política do país. ${ }^{3}$

Entre as oligarquias, enquanto as tradicionais de Minas Gerais e São Paulo começaram a apresentar cisões, outras, dissidentes, como a do Rio Grande do Sul e algumas do nordeste iniciaram processo de fortalecimento. ${ }^{4}$ Essa conjuntura política composta pela ascensão de novos protagonistas e enfraquecimento de antigos

2 Foi desta maneira que ideias anarquistas e socialistas chegaram às cidades brasileiras, no início do século XX. Cf. CARONE, 1972, p. 191-193; FAUSTO, op. cit. p. 297-303; GARCIA, op.cit., p. 510-515; LINHARES, op. cit. 320-321.

3 MENDONÇA, Sônia Regina. A consolidação da República oligárquica. In LINHARES, Maria Yedda (org). História geral do Brasil. 9a ed. Rio de Janeiro: Elsevier, 1990, p. 320.

4 CARONE, 1974a, p. 56-58; FAUSTO, op.cit., p. 316-321. 
grupos hegemônicos foi responsável pela crescente animosidade no Brasil, durante a década de 1920. Dessa maneira, o contexto político caracterizou-se pela insatisfação de setores da sociedade brasileira alijados do processo de decisão desde início do século: operários, camadas médias urbanas, forças armadas e crescente número de oligarquias dissidentes demandavam a implantação do voto secreto, a criação de uma justiça eleitoral, a disponibilização de educação pública obrigatória, a independência do Legislativo e do Judiciário em relação ao Executivo e maior moralidade política e administrativa no país. ${ }^{5}$

A eleição de Artur Bernardes demonstrou o clima tenso vigente à época. $O$ político mineiro foi candidato com apoio das oligarquias dominantes de Minas Gerais e São Paulo. Seu opositor, Nilo Peçanha, candidato pela Reação Republicana, recebeu suporte de oligarquias dissidentes de estados, como Rio de Janeiro, Pernambuco, Bahia, Rio Grande do $\mathrm{Sul}^{6}$, e de grupos do Exército ligados a Hermes da Fonseca, como os jovens tenentes. ${ }^{7}$ Apesar de significativa quantidade de ameaças e hostilidades direcionadas ao político mineiro, as eleições ocorreram e o candidato do Partido Republicano Mineiro foi declarado vencedor.

Com a posse de Artur Bernardes na Presidência da República, setores do Exército que apoiavam o Marechal Hermes da Fonseca aumentaram sua insatisfação política, contribuindo para a ascensão dos tenentes como ator social importante no período. Constituído por jovens oficiais das Forças Armadas e das Forças Públicas estaduais, o movimento denominado "tenentismo" representou ações de um grupo específico de militares vinculados a uma ideologia dentre outras então em voga no Exército Brasileiro. Por essa razão, as ações dos tenentes entre 1920 e 1930 não podem ser consideradas como representantes da política institucional de nenhuma das Forças Armadas ${ }^{8}$.

5 CARVALHO, 2006, p. 89-95; IGLESIAS, op. cit. p. 225; FAUSTO, op. cit. p. 300, 313-315; LINHARES, op. cit. p. 318-319.

$6 \quad$ CARONE, 1974a, p. 56-57; FAUSTO, op. cit. p. 305-307.

7 O episódio das cartas falsas com autoria atribuída ao então governador de Minas Gerais aumentaram de modo significativo a rejeição dos jovens tenentes à Artur Bernardes. Uma das cartas fazia alusão ao banquete promovido pelo Marechal Hermes da Fonseca por ocasião de sua posse na presidência do Clube Militar e continha difamações e impropérios contra o ex-presidente. Mesmo depois de descoberta a farsa e de os responsáveis por ela terem confessado a autoria, forte oposição militar à candidatura do oligarca mineiro manteve-se.

8 CARVALHO, 2005, p. 14; MCCANN, op. cit., p. 326, 336-340. 
Segundo José Murilo de Carvalho, havia três grupos com três diferentes ideologias dentro da força terrestre. A primeira defendida a ideia de "soldadocidadão", em que, além das obrigações militares, todos os membros do Exército tinham o dever de exercer papel cívico ativo na esfera política. Tal corrente surgiu ao final do Império e esteve vinculada aos defensores do positivismo. Essa visão ressurgiu na década de 1920 por meio dos ideais dos jovens tenentes rebeldes ${ }^{9}$. O argumento utilizado à época era que a "força armada é (...) parte integrante do povo." "Os tenentes pregavam uma intervenção reformista a ser feita pelo militar independente da organização, ou mesmo contra ela". ${ }^{11}$

Em oposição a essa vertente, a segunda ideologia defendia o distanciamento do Exército da vida política nacional como condição para uma profissionalização militar adequada ${ }^{12}$. Os jovens oficiais que realizaram estágio no exército alemão, entre 1906 e 1910, em sua maioria, permaneceram à margem das contestações de seus pares, durante a década de $1920^{13}$. Ao contrário da corrente ideológica anterior, essa perspectiva fomentava a unidade da instituição, fortalecendo o Exército ${ }^{14}$ e possibilitando o surgimento de uma terceira ideologia. ${ }^{15}$

O terceiro conjunto de ideias reunia características das duas anteriores, mas se diferenciava pela defesa de aspectos centralizadores e hierárquicos. Os militares adeptos de tal posicionamento admitam a indispensabilidade de profissionalizar o corpo do Exército e a necessidade de eventuais intervenções na vida política e social do país. No entanto, entendiam que somente por meio de uma intervenção centralizada e planejada pelo alto escalão - no caso o Estado-Maior do Exército seria possível uma política da instituição Exército ao invés de várias políticas realizadas no interior dessa Força Armada. Essa racionalidade teria o objetivo de

9 CARVALHO, 2005, p. 38-40. A vasta maioria dos oficiais participantes da Coluna Prestes agiu motivada por essa primeira ideologia. Os rebeldes opuseram-se a seus superiores e às autoridades civis da época em prol de princípios que julgavam ser de interesse nacional.

10 TAVORA, Juarez. À guisa de depoimento sobre a revolução brasileira de 1924. São Paulo: O Combate, 1927. $1^{\circ}$ vol. p. 89. apud CARVALHO, 2005, p. 39. O problema da perspectiva de "soldado cidadão" era o enfraquecimento do princípio da hierarquia. Se necessária, a atuação do militar poderia ocorrer mesmo em oposição a seus superiores, já que os ideais da pátria estariam acima de tudo.

11 CARVALHO, 2005, p. 42; MCCANN, op. cit., p.326.

12 MCCANN, op. cit. p. 338.

13 Esses militares ficaram conhecidos como "Jovens Turcos".

14 MCCANN, op. cit. p. 334.

15 CARVALHO, 2005, p. 40-41; MCCANN, op. cit. p. 339. 
extinguir a ideia de intervenções de cunho contestatório para dar lugar a uma intervenção controladora. ${ }^{16}$

Não conseguindo dar vazão a suas reivindicações políticas e sociais e sendo estimulados pela insatisfação com a situação profissional na carreira militar e pela discordância ideológica existente no interior das Forças Armadas, os jovens tenentes passaram a contestar de modo violento a ordem vigente, por meio de rebeliões armadas, que refletiam o desejo de mudança social e política do país, assim como alterações nas estruturas institucionais das Forças Armadas. A década de 1920 foi caracterizada por várias revoltas nesse sentido, denominadas em seu conjunto "tenentismo". Esse foi o contexto no qual a Coluna Prestes teve sua origem.

\section{Os movimentos revolucionários e a formação e marcha da Coluna Prestes}

No agitado contexto de eleições para o executivo dos estados em 1922, o então presidente Epitácio Pessoa determinou a prisão do Marechal Hermes da Fonseca e o fechamento do Clube Militar, após divergências com esse militar. Esses dois fatos serviram como estopim para a eclosão de movimentos revolucionários planejados pela jovem oficialidade, que ganharam força com a posse de Artur Bernardes na Presidência da República.

Nos dois primeiros anos da década de 1920, várias conspirações ocorreram em São Paulo, Pernambuco, Rio Grande do Sul, Mato Grosso e Rio de Janeiro, no entanto, somente nos dois últimos estados houve ação rebelde, ainda que pouco eficiente $^{17}$. O Levante na Escola Militar do Realengo e o Levante do Forte de Copacabana, em 5 de julho de $1922^{18}$, ambos no Rio de Janeiro, foram os primeiros de várias ações contestatórias que surgiram entre 1922 e $1930 .^{19}$

Dois anos após o movimento dos Dezoito do Forte, eclodiu em São Paulo, na

\footnotetext{
$16 \quad$ CARVALHO, 2005, p. 41-43.

17 CARONE, 1974b, p. 353-354.

18 O Levante do Forte de Copacabana deu origem ao que ficou conhecido na historiografia como os Dezoito do Forte. Para maiores informações ver CARONE, 1974b; CURVO, 2005; MCCANN, 2007; FAUSTO, 2008.

19 Para maiores informações ver CARONE, 1974b, p. 357; CURVO, 2005, p. 41.
} 
mesma data, sublevação liderada pelo general Isidoro Dias Lopes. ${ }^{20}$ Enfrentando dificuldades não previstas, após 4 dias de lutas entre as forças rebeldes e as tropas legalistas, o movimento revolucionário fez o Presidente do estado de São Paulo, Carlos de Campos, abandonar o palácio dos Campos Elíseos. No entanto, após tomarem o controle da capital paulista, os rebeldes não puderam suportar a contraofensiva do governo. Mesmo tendo resistido durante 23 dias a lutas e bombardeios aéreos, na madrugada do dia 28 de julho de 1924, os rebeldes abandonaram São Paulo e marcharam em direção ao oeste do estado do Paraná.

A partir de então, em apoio à rebelião de Isidoro Dias Lopes, diversas revoltas militares eclodiram por todo o país ${ }^{21}$ sem que, no entanto, os rebeldes paulistas soubessem. Uma das primeiras providências tomadas por Artur Bernardes, como modo de assegurar ordem ao país, foi o estado de sítio, decretado no mesmo dia da eclosão da revolta em São Paulo ${ }^{22}$. Com isso, o governo central obteve controle das notícias que circulavam nos maiores jornais nacionais e pôde abafar as repercussões de várias rebeliões, liberando informações de viés pró-governo depois de 3 a 15 dias da ocorrência dos fatos. ${ }^{23}$

Nesse contexto, aconteceu movimentação revolucionária no Rio Grande do Sul. Um contingente de oficiais rebeldes, de vários quartéis do estado, planejou ações para sublevar-se, estabelecendo certo grau de coordenação com os militares de São Paulo, em especial com Juarez e Joaquim Távora. A atuação do capitão Luis

20 O plano dos oficiais rebeldes era simples. Na madrugada do dia 5 de julho de $1924-$ exatamente dois anos após o levante dos Dezoito do Forte de Copacabana -, os quartéis do Exército e da Força Pública do estado de São Paulo seriam sublevados de modo sincronizado, sem derramamento de sangue. Após ganhar o controle da capital do estado, os revoltosos marchariam até o Rio de Janeiro, para depor o presidente Artur Bernardes, alijando do poder não somente a pessoa que consideravam inimiga do Exército, mas também todo o estamento político por ele representado: as corruptas oligarquias regionais que colocavam seus interesses particulares acima dos nacionais e utilizavam os instrumentos burocráticos do Estado para auferir benefícios privados. Cf., entre outros, FAUSTO, 2008, p. 313-315; CARVALHO, 2006, p. 83; CARVALHO, 2005, p. 48-50; MCCANN, op. cit. p. 346-350; MEIRELLES, op. cit. p. 42-43.

21 O Segundo 5 de Julho fez surgir outras revoltas, solidárias aos ideais e aos propósitos dos rebeldes paulistas. Assim, sublevações de unidades militares ocorreram em Sergipe, Mato Grosso, Amazonas e Pará. Como punição pelo envolvimento direto ou indireto no levante do Forte de Copacabana, o Governo Federal transferiu para organizações militares distantes vários oficiais subalternos. Essa ação, no entanto, ao invés de arrefecer os ímpetos dos rebeldes, ajudou a disseminar o espírito revolucionário para outros pontos do país. Cf. CURVO, op. cit. p. 47; MEIRELLES, op. cit. p. 218.

22 MEIRELLES, op. cit. p. 76-78.

23 MEIRELLES, op. cit. p. 101. 
Carlos Prestes foi fundamental para a revolta iniciar-se nessa região. ${ }^{24}$ Apesar de todo o planejamento prévio e de terem estabelecido linhas de abastecimento que julgavam confiáveis ${ }^{25}$, os rebeldes não conseguiram manter sob seu controle a maior parte das unidades militares rebeladas no sul. Logo após a eclosão dos levantes nos quartéis, a atuação repressora do governo foi significativa, obrigando os revoltosos a marcharem na direção do oeste de Santa Catarina e Paraná.

O encontro dos revolucionários paulistas e gaúchos em Foz do Iguaçu marcou o conflito entre duas percepções militares diferentes. A guerra de posição clássica - ensinada pela Missão Francesa ao Exército Brasileiro e arraigada nas estratégias dos oficiais mais velhos - e a guerra de movimento - defendida por Prestes e pelos oficias que vieram com a coluna gaúcha, em função dos êxitos obtidos durante a marcha entre o Rio Grande do Sul e o oeste do Paraná. Em carta a Isidoro Dias Lopes, Prestes já havia deixado claro sua visão militar a respeito do Exército e do movimento rebelde à época:

A guerra no Brasil, qualquer que seja o terreno, é a guerra de movimento. Para nós revolucionários, o movimento é a vitória. A guerra de reserva é a que mais convém ao governo que tem fábricas de munição, fábricas de dinheiro e bastantes analfabetos para jogar contra as nossas metralhadoras. (PRESTES, apud MOREIRA LIMA, 1979, p. 110²6)

Também em Foz do Iguaçu, os revolucionários decidiram enviar à Argentina o seu comandante, o marechal Isidoro Dias Lopes, com a finalidade de estabelecer e manter ativa rede de abastecimento bélico e de víveres que daria condições de o movimento perdurar e, eventualmente, triunfar $^{27}$.

$24 \quad$ PRESTES, op. cit. p. 117-119; CURVO op. cit. p. 50.

25 MEIRELLES, op. cit. p. 303-304; PRESTES, op. cit. p. 132. Por alguma razão, as autoridades argentinas que haviam sido subornadas para permitir a passagem de armamentos negaram-se a cumprir com o acordado. Tanto Meirelles quanto Prestes atribuem tal fato a pressões da chancelaria brasileira junto à Argentina, no sentido de cobrar do país vizinho maior vigilância do trafego de pessoas e de bens em sua fronteira com o Brasil. Apesar de tal explicação ser verossímil, ela não pode ser estendida ao ponto de afirmar-se que o compromisso argentino com as autoridades brasileiras foi cumprido com o mesmo rigor, durante toda a campanha da Coluna.

26 Trecho de carta de Luis Carlos Prestes ao marechal Isidoro Dias Lopes, escrita em Barracão, Paraná.

27 Duas questões são passíveis de controvérsia e merecem atenção: o nome da Coluna e em que momento ela surgiu. O movimento rebelde teve como líder formal o marechal Isidoro Dias Lopes. A marcha realizada pelo país ficou sob comando direto de Miguel Costa, mas foi marcada pela ascensão da liderança de Luis Carlos Prestes. Assim sendo, optou-se pelo nome de "Coluna Prestes" em função de esta nomenclatura ter sido escolhida por Moreira Lima, integrante da Coluna 
Do oeste do Paraná, os rebeldes atravessaram parte do território paraguaio e retornaram ao Brasil em Mato Grosso. A partir daí, marcharam até Goiás, subindo para o Maranhão, Piauí, Ceará. Em seguida, passaram a se direcionar para o Rio Grande do Norte, passando por Paraíba, Pernambuco e Bahia. Graças à movimentação da Coluna Prestes, o governo central e as oligarquias regionais não conseguiram deter o avanço da marcha rebelde. No entanto, a experiência pela região Nordeste do país fez desaparecer, nos revoltosos, a esperança de incendiar as massas populares e obter apoio a suas aspirações políticas. ${ }^{28}$ As adesões à Coluna ocorriam, mas as deserções também. Assim, a quantidade de integrantes da marcha oscilou entre 800 e 1400 pessoas durante todo o trajeto, ficando muito aquém do necessário para empreender um avanço sobre o Catete.

A entrada da Coluna em Minas Gerais ocorreu mais por necessidade que por escolha. Ao atingir o norte de Minas, o alto comando da Coluna já havia decidido emigrar para o exterior, dada as condições políticas e militares que enfrentavam. Em primeiro momento, tal decisão só foi compartilhada entre comandantes da Coluna, nem mesmo os oficiais sabiam dela. ${ }^{29}$ Posteriormente, com o desenrolar da marcha, a necessidade de buscar abrigo no exterior ficou clara para todos.

Da região norte de Minas Gerais, a Coluna retornou à Bahia, indo até Remanso, às margens do rio São Francisco, voltando a Mundo Novo e cruzando o estado até Rondelas, onde transpuseram o rio em direção a Pernambuco. Em

e responsável direto pela elaboração do diário de campanha dos rebeldes. Escolheu-se Foz do Iguaçu como o local de surgimento da Coluna Prestes em função do fato de que, até o encontro entre as forças paulistas e gaúchas, na cidade paranaense, o movimento revolucionário não tinha seu destino determinado. Mesmo que a intenção de Prestes, desde o início, tenha sido a de empreender uma guerra de movimento contra o governo federal, essa estratégia só foi absorvida pelo Estado-Maior revolucionário em Foz do Iguaçu. Neste local, ficou acordado que os rebeldes deveriam marchar pelo país, esperando engrossar as fileiras rebeldes, para, em seguida, derrubar Artur Bernardes.

28 A dura realidade encontrada fez os jovens tenentes compreenderem que a dominação das elites sobre as camadas mais humildes da sociedade brasileira ocorria de modo muito mais intenso e complexo do que supunham. A fome e a miséria grassavam o interior brasileiro, e, na maioria das vezes, a única maneira de diminuir ou amenizar os nefastos efeitos desse quadro era associar-se aos líderes locais. Assim, os rebeldes compreenderam que suas reivindicações por voto secreto, maior transparência na gestão do Estado e livre manifestação dos grupos de oposição pertenciam a uma realidade distante para as camadas populares nacionais. Antes de preocupar-se com tais aspectos da cidadania civil e política, a maior parte da população ainda se preocupava com a obtenção de meios básicos de subsistência.

29 MOREIRA LIMA, op. cit. p. 306-307; MEIRELLES, op. cit. p. 532-533; PRESTES, op. cit. p. 268-270. 
seguida, entraram no Piauí, atravessaram Goiás, seguiram para a região sul de Mato Grosso, retornaram a Goiás e, por fim, cruzaram a região norte de Mato Grosso até internarem-se em San Matias e Guaíba, na Bolívia.

Após dois anos e meio de marchas, lutas e combates, a Coluna Prestes percorreu mais de 25 mil quilômetros. Até os dias de hoje, a distância total da Coluna continua sendo objeto de polêmica. Dependendo da soma de quilômetros atribuídos aos rebeldes, esse feito pode ser considerado como a primeira ou a segunda maior marcha militar da história humana, disputa que tem como contraparte o percurso de 27.500 quilômetros, feito por Alexandre, o Grande. Desse modo, não foi somente pelo fato de Luiz Carlos Prestes ter-se tornado comunista que tal empreendimento foi difundido na China, na União Soviética, na lugoslávia e em outros países comunistas. A Grande Marcha de Mao Tsé Tung, por exemplo, foi realizada baseando-se nos feitos da guerra de movimento da Coluna Prestes e, ao contrário do movimento brasileiro, tornou-se conhecida também no mundo ocidental. ${ }^{30}$

Certamente o fato de a Grande Marcha ter-se tornado base para a vitoriosa Revolução Chinesa contribuiu bastante para sua difusão. Em contrapartida, o fato de Prestes ter-se tornado comunista em 1930, ter incitado a Intentona Comunista em 1935 e ter-se transformado em inimigo do regime getulista contribuiu para que tudo vinculado ao seu nome fosse relegado a segundo plano na história do Brasil. Mesmo após a queda de Vargas, o contexto de Guerra Fria da segunda metade do século XX foi outro empecilho para a desideologização da história nacional.

Nas últimas décadas, no entanto, isso tem sido alterado. Novos estudos a respeito da Coluna Prestes apresentam análises mais objetivas, na medida em que se abstêm de propagandas políticas e focam na compreensão da lógica subjacente aos acontecimentos ligados ao evento. Vale lembrar que, até 1927, Prestes ainda não havia tido contato com o pensamento marxista-leninista, tendo-se convertido a ele na Argentina, entre 1928 e 1930.

Como será visto, ao longo de todo o período em que a marcha percorreu o país, a rede de contatos entre a Coluna Prestes e rebeldes localizados na Argentina SOUTO MAIOR, 2006, p. 27-47. 
foi sistematicamente vigiada pelo governo federal com todos os recursos de que dispunha: serviço de inteligência, informantes e redes consular e diplomática brasileira no exterior, principalmente a existente na região do Prata. Além das repercussões internacionais e das perturbações domésticas, a influência da marcha rebelde na Política Externa Brasileira pode ser auferida por meio dos telegramas trocados entre os postos platinos do Brasil, de um lado, e a Secretaria de Estado do Ministério das Relações Exteriores, no Rio de Janeiro, de outro.

\title{
AS INFLUÊNCIAS DA COLUNA PRESTES SOBRE AS RELAÇÕES INTERNACIONAIS DO BRASIL
}

\section{A política externa do Brasil na década de 1920}

Embora a Política Externa Brasileira tenha apresentado continuidade em vários aspectos, desde o início da República Velha, a atuação externa brasileira sofreu oscilações decorrentes de opções políticas e preferências diplomáticas elaboradas de acordo com necessidades de cada momento. ${ }^{31}$ Segundo Eugênio Vargas Garcia, a década de 1920 foi caracterizada por três eixos de ação da política externa brasileira: os Estados Unidos, a Europa e a América do Sul. A análise da ação externa, nesse período, deve levar em conta:

\begin{abstract}
um contexto interno de crise política e institucional, prevalência do modelo agroexportador, dificuldades econômicas, dependência do capital estrangeiro e limitada capacidade estratégico-militar. Convém assinalar que a formulação e a execução da política externa estavam dominadas por pequeno círculo de elite, basicamente atores ligados ao Ministério das Relações Exteriores e a setores do governo federal. (GARCIA, 2006, p. 25)
\end{abstract}

"Na cultura política oligárquica, a 'amizade' pressupunha compromissos e obrigações mútuas entre os membros da comunidade. A amizade entre iguais significava aliança, a amizade entre desiguais, proteção em troca de lealdade." ${ }^{32}$ Enquanto o Brasil interpretava sua relação com os EUA como sendo entre iguais, os

31 BREDA DOS SANTOS, 2003, p. 89-88; CERVO, 1994, 226-228; GARCIA, op. cit., p. 25-26.

$32 \quad$ GARCIA, op. cit. p. 585. 
norte-americanos não recebiam o que esperavam pela proteção prestada, e esse quadro gerava dissonâncias nas relações entre os dois países, fazendo que ambos tivessem dificuldades em compreender as ações externas um do outro. As expectativas norte-americanas de lealdade brasileira não se confirmaram, porque a política externa brasileira não se baseava em um "alinhamento automático" com os EUA, na década de 1920. A recusa do Brasil em assinar o Pacto Briand-Kellog - ou Tratado de Paris - e a decisão de não se retirar da Liga das Nações, em um primeiro momento, demonstraram tal assertiva. ${ }^{33}$

Em relação à Europa, a política externa brasileira tinha como principais preocupações questões comerciais e financeiras. O envolvimento do Brasil em assuntos políticos no Velho Continente buscava dotar o país de prestígio internacional $^{34}$ Lutando por um assento permanente no Conselho da Liga das Nações, o Brasil pareceu demonstrar não ter calculado bem seu peso na esfera internacional, à época, e acabou por gerar crise significativa no âmbito da Liga, ao vetar a entrada da Alemanha na organização e, depois, anunciar sua retirada do Conselho e da própria Organização. ${ }^{35}$

No âmbito da América do Sul, a diplomacia brasileira não se pautou por questões econômicas, uma vez que o comércio exterior do país era feito majoritariamente com os EUA e com a Europa, nos anos de 1920. As principais preocupações do Brasil em relação à sua vizinhança passavam por aspectos estratégicos, militares e políticos. Sentido a necessidade de modernizar e reequipar suas Forças Armadas, o Brasil buscou atuar no cenário internacional de modo a obter legitimidade para seu empreendimento. Tal fato, no entanto, foi responsável por aumentar a rivalidade com a Argentina, gerando tensões entre os dois países. ${ }^{36}$

33 CUNHA, 2008, p. 30-32; GARCIA, op. cit. p. 585-587.

$34 \quad$ BREDA DOS SANTOS, op. cit. p. 88-89; GARCIA, op. cit. p. 589.

35 CERVO, op. cit., p. 224-227; GARCIA, op.cit., p. 412-414; SILVA, 1998, p. 149-150.

36 GARCIA, op. cit. p. 587-588. Os efeitos dos esforços brasileiros para modernizar suas Forças Armadas foram prejudiciais à imagem externa do país. Após a I Guerra Mundial, tópicos sobre desarmamento e limitação da capacidade bélica dos países dominavam a agenda internacional. Desse modo, a diplomacia nacional trabalhou no sentido oposto ao do restante do mundo e suscitou desconfianças em sua vizinhança. Desde a chancelaria de Rio Branco, a rivalidade com a Argentina já se havia intensificado. O temor de uma "relação especial" entre Brasil e Estados Unidos e o desejo do primeiro em reequipar-se militarmente despertaram temores nos argentinos. Para mais detalhes, ver GARCIA, op. cit. p. 218-221; 587-588; PARADISO, op. cit. p. 109-110. 
Amado Cervo e José Carlos de Macedo Soares concordam que a atribulada gestão de Félix Pacheco era uma maneira de tentar neutralizar as repercussões das revoltas internas na esfera internacional e no âmbito doméstico. ${ }^{37}$ Eugênio Vargas Garcia demonstrou como o corpo burocrático do Ministério das Relações Exteriores - MRE - foi utilizado para tentar neutralizar os efeitos e as repercussões danosos que os movimentos domésticos de contestação tiveram no exterior. ${ }^{38}$

Exemplo desse fato pode ser encontrado, ao analisar a marcha da Coluna Prestes. Esse movimento causou repercussão principalmente na América do Sul. As missões diplomáticas do Brasil em Assunção, Buenos Aires, Montevidéu e La Paz mandavam ao Rio de Janeiro informes e outras correspondências diplomáticas com frequência, dando ciência ao governo federal dos passos dos jovens oficiais ${ }^{39}$. Dessa maneira, a política externa platina do Brasil, durante o mandato de Bernardes e início de Washington Luis, empreendeu significativo esforço junto às nações vizinhas, para neutralizar o empreendimento logístico da Coluna e amenizar as más repercussões advindas do combate contra ela. ${ }^{40}$

Os esforços do MRE para combater a atuação da Coluna Prestes nos países vizinhos ocorreram em contexto de tensão, desconfiança e incompreensão entre Argentina e Brasil. Ao longo desse período, a Coluna Prestes obrigou o Itamaraty a permanecer de prontidão para atuar junto a países vizinhos sempre que atividades rebeldes eram detectadas em territórios estrangeiros. Se a cooperação auferida pelo Brasil junto às autoridades paraguaias e uruguaias, por exemplo, foi tida como satisfatória, o mesmo não ocorreu em relação à Argentina, conforme se depreende dos telegramas trocados entre a embaixada do Brasil em Buenos Aires e a Secretaria de Estado, no Rio de Janeiro.

\section{O Itamaraty no combate à Coluna Prestes e aos movimentos que deram}

\footnotetext{
$37 \quad$ CERVO, op. cit. p. 226-227.

38 CURVO, 2005, p. 89-93; GARCIA, op. cit. 491-492 e 601; AHI 202/02/01, AHI 208/02/03; AHI 208/02/04; AHI 208/02/05; AHI 208/02/06; AHI 208/03/01, AHI 208/03/02, AHI, Lata 46, maço 378.

39 GARCIA, op. cit. 548; AHI 202/02/01, AHI 208/02/03; AHI 208/02/04; AHI 208/02/05; AHI 208/02/06; AHI 208/03/01, AHI 208/03/02, AHI, Lata 46, maço 378.

40 GARCIA, op. cit. p. 541-552; AHI 202/02/01, AHI 208/02/03; AHI 208/02/04; AHI 208/02/05; AHI 208/02/06; AHI 208/03/01, AHI 208/03/02, AHI, Lata 46, maço 378.
} 


\section{origem à marcha rebelde}

Como visto, durante o período em que a marcha da Coluna Prestes percorreu o país, os rebeldes estabeleceram rede de contatos com os membros do movimento que estavam localizados na Argentina. Essas comunicações foram feitas por meio de enviados que viajavam até o país estrangeiro e, depois, retornavam ao Brasil. Em alguns casos, a comunicação foi realizada por meio de telegramas e correspondências. As ações dos revolucionários foram vigiadas pelo governo federal com todos os recursos de que dispunha: serviço de inteligência, informantes e rede consular e diplomática brasileira no exterior.

Entre os anos de 1924 e 1929, as missões estrangeiras brasileiras em Montevidéu, Assunção e, principalmente, Buenos Aires foram instrumentos importantes para a política externa de repressão iniciada por Bernardes e continuada por W. Luis. Assim sendo, a questão não foi meramente pessoal, como grande parcela dos autores que escrevem sobre o tema afirma, posto que um dos objetivos declarados pelos insurgentes era a queda do governo de Artur Bernardes ${ }^{41}$.

Ao longo desse período, a Coluna Prestes obrigou o Itamaraty a permanecer de prontidão para atuar junto aos países vizinhos - sempre que atividades rebeldes eram detectadas nesses territórios - e junto aos demais países que tinham interesses econômicos ou sociais no Brasil, derivados de fluxos financeiros e migratórios.

\section{A repercussão dos levantes no exterior e as reclamações estrangeiras}

Desde a eclosão do Segundo 5 de Julho, em 1924, o movimento liderado por Isidoro Dias Lopes produziu repercussões nas relações internacionais do Brasil. As primeiras consequências foram notícias divulgadas no exterior a respeito do movimento revolucionário, gerando imagem negativa do país. A imprensa internacional auferia informações diretamente de seus representantes no Brasil ou por troca de dados entre si. O governo federal deu orientação aos postos do 
Itamaraty para que atuassem no sentido de desmentir notícias referentes aos movimentos rebeldes que fossem consideradas infundadas ou mentirosas. Isso ocorreu na Europa e na América do Sul, onde as embaixadas e as legações do Brasil publicaram, por diversas vezes, matérias, notas e cartas com a intenção de reforçar as versões oficiais sobre as agitações no país. ${ }^{42}$

A guerra de informações entre o governo federal e as agências estrangeiras foi tão significativa que Artur Bernardes passou a censurar não só as notícias que circulavam internamente, como também as informações que os correspondentes estrangeiros enviavam ao exterior ${ }^{43}$. Ainda assim, as informações levantadas pelas agências norte-americanas eram bem fidedignas aos fatos, e isso pode ser decorrente da provável atuação dos consulados norte-americanos como fontes para a mídia. A reprodução em Buenos Aires de grande parte das notícias publicadas pelos meios norte-americanos é outro indício da qualidade dessas informações. ${ }^{44}$ Como a versão oficial era muito diferente das que circulavam nos jornais estrangeiros, houve protestos brasileiros junto às embaixadas desses dois países e repercussões, inclusive, na Europa ${ }^{45}$. Em nota ao encarregado de negócios da embaixada dos EUA, Pacheco justificou suas ponderações, afirmando que "o

42 AHI 215/01/04; AHI, 215/01/05; Toledo a Pacheco, tels. no 93, 94, 96, 97, 98, 100, 101, 103, 105, 107, entre outros, de Buenos Aires, de 1924, AHI 208/02/03.

43 Pacheco a Toledo, tel. n 45, RJ, 11 nov. 1924, AHI, 208/03/01; MEIRELLES, 1997, p. 102, 113-114, 117, 137-138, 162.

44 Toledo a Pacheco, tel. $n^{\circ}$ 91, Buenos Aires, 12 jul., 1924, AHI 208/03/02; Toledo a Pacheco, tel. $n^{\circ}$ 94, Buenos Aires, 14 jul. 1924, AHI, 208/02/03; MEIRELLES, op. cit. p. 123, 206, 265, 351. Isso já não é válido para os meios de comunicação da Argentina, que, por vezes, publicaram boatos sem fundamento, como foram os casos do jornal La Prensa, que chegou a afirmar que o Presidente Artur Bernardes renunciaria a seu mandato em novembro de 1924 - Toledo a Pacheco, tel. $n^{\circ} 156$, Buenos Aires, 24 set., 1924, AHI, 208/02/03 - e do La Nación que, em 1925, também afirmou que o Presidente brasileiro renunciaria em alguns meses - Toledo a Pacheco, tel. $n^{0} 15$, Buenos Aires, 11 jan., 1925, AHI, 208/02/04.

$45 \quad$ Exemplo disso pode ser encontrado em Portugal. À época, o embaixador brasileiro em Lisboa, José Manoel Cardoso de Oliveira, desmentiu vários pontos contidos na entrevista concedida por J. J. Seabra e Irineu Machado a jornais portugueses. Vale lembrar que Seabra havia sido candidato a vice-presidente da República, em 1922, na chapa de oposição a Bernardes, liderada por Nilo Peçanha, enquanto Machado havia sido deputado e senador da República pelo Distrito Federal. As notas de José Manoel Cardoso de Oliveira direcionadas aos meios de comunicação portugueses reproduziram as informações enviadas pelo governo federal, no Rio de Janeiro, reforçando, assim, a versão oficial sobre os levantes. Como se verá mais adiante, o controle exercido pelo Itamaraty foi tão estrito que nenhuma ação deveria ser tomada sem o prévio consentimento de Pacheco. É nesse sentido que o embaixador brasileiro em Lisboa repreendeu um cônsul e, de acordo com instruções recebidas de Pacheco, Pedro de Toledo também deveria fazer o mesmo com relação ao cônsul brasileiro em Paso de los Libres. Para o caso português cf. AHI, 215/01/04 e AHI, 215/01/05. Para o caso em Paso de los Libres, cf. Pacheco a Toledo, tel, n²62, RJ, 2 nov. 1924, AHI, 208/03/01. 
Governo seria, portanto, ingênuo, se não se defendesse desse noticiário malévolo e corrosivo que semeia a anarquia no País e abala seu crédito no exterior"46. $\mathrm{O}$ embaixador brasileiro em Buenos Aires, Pedro de Toledo, tentou alertar Pacheco sobre as más repercussões da censura e dos protestos, mas sem sucesso: ${ }^{47}$

\begin{abstract}
A imprensa, unânime, aqui, comenta, como desfavorável ao Brasil, o excessivo rigor da censura que cerca de mistérios os acontecimentos de São Paulo, sem o complemento de explicações mais amplas que as dos comunicados por parte do governo brasileiro. Nos meios políticos mais simpáticos ao Brasil domina a mesma impressão, manifestada sempre em tom amistoso. Justificam a censura, mas julgam necessária uma válvula para socorrer a opinião dos próprios amigos. (Toledo a Pacheco, tel. $\mathrm{n}^{\circ} .98$, Buenos Aires, 16 de julho, 1924, AHI 208/02/03)
\end{abstract}

As notas do governo tinham tom otimista. A versão oficial dos acontecimentos entre 1922 e 1927 considerou os levantes como meros distúrbios sem maior importância, minimizando as ações dos revolucionários. A realidade, no entanto, era diversa. A princípio, a estratégia do governo funcionou bem nos grandes centros urbanos, mas, conforme os anos passavam, ficava evidente para todos que as versões oficiais não eram confiáveis, já que a marcha revolucionária continuava a desafiar os efetivos das Forças Públicas e do Exército Brasileiro.

O controle do governo federal sobre as informações fez que o Itamaraty não informasse a suas missões no exterior o estado real em que o país se encontrava. $O$ governo brasileiro subestimava os rebeldes e enviava a seus postos diplomáticos informações pouco confiáveis. Exemplos desses fatos e da guerra de informações entre o MRE e os jornais estrangeiros são encontrados em telegrama da Secretaria de Estado para a Embaixada do Brasil em Buenos Aires, de julho de 1925:

São inteiramente inexatas notícias aí publicadas sobre pretendidas vantagens obtidas pelos revolucionários na fuga pelos sertões de Goiás. Os bandos comandados por Prestes e Miguel Costa perderam toda eficiência tendo já sofrido vários revezes infligidos pela Coluna governista comandada

$46 \quad$ Resposta de Félix Pacheco ao encarregado de negócios da Embaixada dos EUA. Rolo 6, fotograma 648, Arquivo Artur Bernardes apud MEIRELLES, 1997, p. 137-138.

47 AHI 215/01/04; AHI 215/01/05; Toledo a Pacheco, tels. $n^{\circ}$ 93, 94, 96, 97, 98, 100, 101, 103, 105,107 , entre outros de 1924, AHI 208/02/03. 
pelo major Klinger. O governo considera extinta a revolução e desnecessárias novas operações militares, bastando medidas de polícia para acabar de dispersar os grupos que abandonaram Mato Grosso e continuam fugindo pelas zonas despovoadas de Goiás. (Pacheco a Toledo, tel. $n^{\circ}$. 98, Buenos Aires, 17 de julho, 1925, AHI 208/03/01)

É verdade que Bertoldo Klinger impôs sérias adversidades aos rebeldes em sua perseguição, mas afirmar que o governo considerava "extinta a revolução" era subestimar os rebeldes ou querer passar às missões brasileiras no exterior falsa impressão do que ocorria de fato, no interior do país. Depois desse telegrama, o movimento rebelde durou por mais um ano e sete meses, tempo suficiente para desacreditar o governo federal e o Exército Brasileiro perante a população do país e fazer crescer a admiração por Prestes e seus comandados em significativas parcelas do próprio Exército e das camadas médias urbanas ${ }^{48}$.

Deste modo, à época dos movimentos rebeldes, nenhum embaixador ou outro servidor lotado no exterior sabia realmente o que se passava no Brasil. A versão do governo era aquela na qual os membros do Itamaraty no exterior acreditavam. É possível que Pacheco pensasse que os postos no exterior cumpririam melhor o papel de desmentir as notícias prejudiciais à imagem brasileira caso conhecessem apenas o que o governo federal desejasse. Seja como for, o MRE atuou de forma incisiva, junto aos países em que as informações consideradas perniciosas eram propaladas, desmentindo tais notícias ${ }^{49}$ e chegando a solicitar maior controle por parte dos governos dessas nações sobre os jornais que publicavam essas matérias. ${ }^{50}$

Além da disputa de versões entre o governo federal e a imprensa internacional, a luta entre os rebeldes e as forças legalistas gerou também outros pontos de tensão nas relações internacionais do Brasil. Como visto, depois de enfrentar significativa resistência de alguns batalhões da Força Pública paulista, os

$48 \quad$ Toledo a Pacheco, tel. $\mathrm{n}^{\circ}$ 386, Buenos Aires, 6 dez., 1924, AHI, 208/02/03.

49 Toledo a Pacheco, tel. $n^{\circ}$ 285, Buenos Aires, 8 nov. 1924, AHI, 208/02/03; Toledo a Pacheco, tel. $n^{\circ} 286$, Buenos Aires, 8 nov. 1924, AHI, 208/02/03.

$50 \quad$ Pacheco a Toledo, tel. $n^{\circ} 37$, RJ, 14 ago. 1924, AHI, 208/03/01; Pacheco a Toledo, tel. $n^{\circ} 32$, RJ, 8 jul. 1924, AHI, 208/03/01; Pacheco a Toledo, tel., RJ, 18 out. 1924, AHI, 208/03/01; Pacheco a Toledo, tel. $n^{\circ}$ 33, RJ, 16 jul., 1924, AHI, 208/03/01; Pacheco a Alves, tel. $n^{\circ}$ 71, RJ, 19 out. 1926, AHI, 208/03/01; Toledo a Pacheco, tel. $n^{\circ}$ 90, Buenos Aires, 12 jul. 1924, AHI, 208/02/03; Toledo a Pacheco, tel. $n^{\circ}$ 125, Buenos Aires, 16 ago. 1924, AHI, 208/02/03. 
revolucionários conseguiram dominar a cidade de São Paulo, obrigando as forças federais a abandonar a capital. A partir desse ponto, o Exército adotou a estratégia de bombardear São Paulo por meio de fogos de artilharia e de operações aéreas. Não tendo conhecimento das posições ocupadas pelos rebelados, as tropas legais passaram a atingir bairros de forma indiscriminada, matando número considerável de civis.

À época, São Paulo tinha grande percentual de imigrantes europeus em sua população, por isso houve elevado número de vítimas de nacionalidade estrangeira. Em treze de julho de 1924, os representantes diplomáticos acreditados nessa cidade reuniram-se com o objetivo de discutir a melhor maneira de protestar contra os bombardeios que estavam prejudicando os interesses comerciais de seus países e matando grande número de seus compatriotas. A quantidade de países presentes refletiu a importância do encontro: do corpo diplomático da cidade, representantes de Itália, Portugal, Chile, Peru, Argentina, Uruguai, Suécia, Dinamarca, França, Bélgica, Estados Unidos, Japão, Espanha, Noruega, Suíça, Alemanha e Inglaterra participaram da reunião ${ }^{51}$.

Uma comissão para tentar negociar diretamente junto aos rebeldes e às forças legais o fim do bombardeio à cidade foi criada, e as negociações ocorreram de forma rápida. Diante do insucesso dessa primeira iniciativa, no dia 15 de julho, outra comissão formada por cinco embaixadores foi criada e recebida por Artur Bernardes no Palácio do Catete. Faziam parte desse grupo os representantes da Grã-Bretanha, John Tilley, da França, Alexandre Conty, da Itália, Pietro Badoglio, de Portugal, Duarte Leite e da Bélgica, barão de Falon. Os cinco membros do corpo diplomático solicitaram que as facilidades de comunicações com seus cônsules, em São Paulo, fossem restabelecidas e que, em caso de bombardeio, a população civil fosse avisada com antecedência, a fim de poder escapar da zona de conflito. $O$ presidente Bernardes prometeu fazer o possível para atender às demandas dos representantes estrangeiros e reiterou sua confiança na restauração da ordem na capital paulista. ${ }^{52}$

\footnotetext{
51 Jornal do Comércio, São Paulo, 19 de julho de 1924 apud MEIRELLES, op. cit. p. 124125. 
No dia 24 de julho, as forças do governo lançaram, sobre São Paulo, panfletos direcionados à população. Segundo o ministro da Guerra, Setembrino de Carvalho, as tropas legalistas necessitavam de que a população paulistana abandonasse a cidade para que os combates aos rebeldes pudessem ocorrer de modo mais eficiente e com maior liberdade de ação. Tal mensagem deu a entender que o governo estava prestes a lançar ação de grande envergadura contra os rebeldes, e, diante dessa possibilidade, parte do corpo diplomático, no Rio de Janeiro, resolveu enviar nota conjunta ao Itamaraty, demonstrando preocupações pela vida de seus nacionais. A mensagem foi assinada pelos chefes das representações diplomáticas de Alemanha, Bélgica, Dinamarca, Espanha, Estados Unidos, França, Grã-Bretanha, Itália, Japão, Países Baixos, Portugal, Suíça e Tchecoslováquia. Os países da América Latina preferiram não assinar o termo por considerá-lo uma intervenção em assuntos internos brasileiros. ${ }^{53}$

Conforme se podia prever pela reação dos diplomatas latino-americanos, a interpretação que Félix Pacheco deu à nota conjunta foi a de uma intromissão inapropriada do corpo diplomático estrangeiro em assuntos essencialmente afetos à esfera doméstica do Brasil. Para o governo federal, o levante em São Paulo era um caso de polícia e, sendo assim, não comportava intromissões de outros países. O chanceler recusou-se a receber a nota coletiva, aceitando, no entanto, sua substituição por notas individuais das missões estrangeiras que quisessem manifestar-se. ${ }^{54}$

No dia 28 de julho de 1924, apenas quatro dias após a elaboração da nota coletiva, os revolucionários abandonaram São Paulo com destino ao interior do país. A partir de então, as missões diplomáticas estrangeiras no Brasil puderam tranquilizar-se em relação às vidas de seus nacionais, por um lado, mas, por outro, passaram a preocupar-se em garantir que os prejuízos decorrentes dos confrontos fossem devidamente reparados àqueles que tivessem sofrido perdas. Enquanto a Grã-Bretanha foi o país que mais perdeu em termos financeiros e comerciais, a Itália foi a nação que mais sofreu em termos humanos, em função do grande número de 
imigrantes deste país vivendo em São Paulo ${ }^{55}$. A extensão do bombardeio causou impacto e indignação no embaixador italiano, conforme consta em carta enviada ao cônsul-geral em São Paulo:

\begin{abstract}
o que vi e ouvi em São Paulo se me contristou o coração italiano, por tudo quanto sofreram os meus irmãos, e me encheu de orgulho (...) porque pude mais uma vez admirar toda a altivez e toda a virtude da nossa raça (...). Sofrimentos e danos gravíssimos foram suportados com força de ânimo digno da antiga Roma (...). Das vítimas inocentes e dos que mais diretamente as choraram, como de todo os que perderam alguma coisa, se lembrará para sempre o Brasil. (BADOGLIO, Pietro apud MEIRELLES, 1997, p. 205)
\end{abstract}

Entre 1924 e início de 1927, as requisições de materiais e equipamentos realizadas pelas forças em conflito também fizeram que diversos países atuassem junto ao Brasil, com o objetivo de obter as reparações devidas. A duração da marcha da Coluna Prestes deveu-se em grande medida às chamadas "requisições" de materiais e viveres realizados junto à população dos lugares por onde passou. $\mathrm{O}$ alto comando rebelde fez diversas requisições de alimentos, roupas, calçados, gado, cavalos e armas, deixando em condições ainda mais miseráveis famílias que tinham pouco ou quase nada para manter-se..$^{56}$

Os rebeldes deixavam por escrito todos os bens que auferiam dos particulares e instruíam-nos a requerer, junto à União, o valor equivalente às requisições feitas. Pela legislação à época - tanto a Constituição, quanto o Código $\mathrm{Civil}^{57}$ - o governo federal era responsável pelo ressarcimento dos bens utilizados por revolucionários, sendo necessário aos particulares:

\footnotetext{
reconhecerem a firma do oficial que assina o documento. Caso o tabelião não pudesse fazer o reconhecimento, os interessados deveriam pedir a duas pessoas que abonassem a firma e autenticar, em seguida, a assinatura dos abonadores. Depois, deveriam comprar um selo proporcional ao do valor do bem requisitado, caso o montante das despesas não estivesse declarado no documento. Após o reconhecimento das firmas, as "requisições" deveriam ser registradas no Cartório de Títulos e Documentos. As pessoas eram ainda alertadas para outro aspecto importante: o prazo para prescrição dessas ações, junto à União, era de cinco anos. (MEIRELLES, 1997, p. 432)
} 
A empresa Mate Laranjeira que cultivava erva-mate no oeste do Paraná e de Santa Catarina procedeu dessa maneira, em 1930, para obter o ressarcimento de seus bens. Entretanto, "o ritual burocrático, com todos os mencionados procedimentos de ordem legal, era liturgicamente incompreensível para a população analfabeta". Esperar conduta como essa de pessoas simples do campo que não tinham acesso, nem mesmo, a cartórios ou advogados era algo ingênuo ${ }^{58}$.

No caso de requisições feitas por tropas legais, a comprovação era mais simples, uma vez que todo material tomado era trocado por declarações de oficiais que haviam realizado tal procedimento, bastando que 0 antigo proprietário apresentasse esse documento e comprovasse o valor de mercado que seu(s) bem(ns) possuía $(\mathrm{m})$ à época. ${ }^{59}$

Em várias situações, no entanto, os trâmites burocráticos sofriam consideráveis delongas, causando perdas aos particulares que tinham crédito a receber junto ao governo federal. Empresas grandes, como a Mate Laranjeira, por exemplo, tinham recursos para pressionar a União e fazer valer seus direitos. No entanto, várias dessas requisições afetaram cidadãos comuns que não tinham poderes econômicos expressivos. No caso de estrangeiros, muitos deles recorreram à proteção diplomática que seus países podiam fornecer-Ihes e solicitaram ajuda de suas missões diplomáticas para resolver pendências financeiras junto ao governo brasileiro.

Em um desses casos, a Itália requereu ao Brasil o pagamento de indenização no valor de 18:582 $\$ 400$ réis a Pilade Baiocchi, comerciante italiano que forneceu "feitos", entre dezembro de 1926 e março de 1927, às tropas federais que combatiam os rebeldes em Goiás. As trocas de correspondência entre a embaixada italiana no Rio de Janeiro, o Ministério da Guerra e o Itamaraty demonstram que houve certa pressão por parte da Itália para solucionar a situação de seus cidadãos $^{60}$.

Um dos casos mais interessantes de reclamação estrangeira ocorreu com $58 \quad$ MEIRELLES, op. cit. p. 433.

$59 \quad$ AHI, Lata 478, maço 7453; AHI, Lata 471, maço 7203.

60 AHI, Lata 478, maço 7453; Toledo a Pacheco, tel. $n^{\circ}$ 232, Buenos Aires, 11 mai., 1925, AHI, 208/02/04. 
súdito holandês de nome Ary de Geus, na região de Carambeí, no município de Castro, Paraná. No início do século, houve significativo afluxo de imigrantes holandeses que vieram trabalhar para a Brazil Raiway Company. Duas famílias foram pioneiras na região: os Leendert e os Verschoor. Estabelecido no local, Jan Verschoor resolveu voltar à Holanda, em busca de novos imigrantes para a então colônia de "Carambehy". Nessa oportunidade, ele entrou em contato com Aart Jan de Geus e despertou interesse de seus filhos Leendert e Ary de Geus em vir morar no Brasil.

Ao terminar as atividades da Brazil Railway Company, vários imigrantes holandeses passaram a trabalhar na empresa de lacticínios fundada por Aart Jan de Geus, denominada De Geus \& Cia. Na década de 1920, surgiram mais duas fábricas de queijo na região, e, para evitar concorrência entre os imigrantes holandeses, foi criada, em 1925, a Sociedade Cooperativa Hollandeza de Laticínios.

Pouco antes, em setembro de 1924, quando as forças legais que combatiam a Coluna Prestes passaram pela região de Carambeí, requisitaram a Ary de Geus três automóveis, vários pneus e outros acessórios que julgaram necessários ao esforço empreendido contra os rebeldes, perfazendo o valor total de 16:968\$000 réis. Em 1925, o senhor de Geus requereu do governo federal a indenização a que fazia jus. ${ }^{61}$

Chama atenção, nesse caso, a participação de um enviado extraordinário e ministro plenipotenciário de Sua Majestade a Rainha dos Países Baixos, o senhor van Rappard. Como o governo de Artur Bernardes não solucionou a questão, a pendência do caso de Geus chegou a 1929, sem desfecho. Nesse contexto, a legação holandesa no Brasil pediu auxílio ao então ex-chanceler Félix Pacheco para realizar gestões junto a Otávio Mangabeira, ministro que Ihe sucedeu no cargo. A troca de notas entre a legação holandesa, Otávio Mangabeira, Félix Pacheco e o ministro da Guerra, Nestor Sezefredo dos Passos, demonstrou que a pressão desse país europeu sobre o MRE foi significativa, tendo o enviado extraordinário, van Rappard, recebido procuração do senhor de Geus para atuar em seu nome e receber a quantia devida. ${ }^{62}$

61 AHI, Lata 471, maço7203.

62 AHI, Lata 471, maço7203. 
Como não há outros documentos relativos ao caso, pôde-se presumir que o pagamento a Ary de Geus ocorreu no ano de 1929 e teve boa serventia para ele e sua família. Um ano antes, em 1928, o cônsul holandês Berkhout sugeriu que a marca dos queijos produzidos pela Cooperativa de "De Geus \& Cia." fosse alterada para "Batavo", em homenagem à população que habitou, na antiguidade, a região holandesa de origem das famílias dos primeiros colonos de Carambeí. Surgiu, dessa maneira, a empresa Batavo, nacionalmente conhecida nos dias de hoje e que, com a eventual indenização recebida do governo federal, teve mais recursos financeiros para as atividades produtivas do início de sua existência. ${ }^{63}$

As críticas da Argentina à política militar e naval do Brasil, a guerra de informações entre o Itamaraty e a imprensa estrangeira, as reclamações das potências européias e dos EUA junto ao Brasil podem gerar a falsa impressão de que o MRE atuou somente na defensiva durante a década de 1920. No entanto, ao reagir perante as demandas externas, a chancelaria brasileira não descuidou do combate aos revolucionários e da precaução contra eventuais ameaças internacionais.

Provas disso são encontradas nas informações levantadas pelo Itamaraty, pelo serviço de inteligência das Forças Armadas e pelos agentes civis do governo. Como exemplo, é digno de destaque o conteúdo de alguns telegramas enviados de Buenos Aires para o Rio de Janeiro, em julho de 1924, que retransmitiram notícias circulantes na capital argentina. Por meio de comunicações entre Pedro de Toledo e Félix Pacheco, foi possível saber que Itália, Estados Unidos e Grã-Bretanha ${ }^{64}$ cogitaram enviar vasos de guerra para Santos, para assegurar interesses comerciais naquele porto. ${ }^{65}$

Pelos telegramas que chegaram à Secretaria de Estado, poder-se-ia imaginar

63 Outras informações sobre a família de Geus foram retiradas da Internet, na página oficial da Prefeitura de Carambeí/PR - município emancipado de Castro, em 13 de dezembro de 1995. Disponível em < http://www.carambei.pr.gov.br/> e <http://www.sppert.com.br/Artigos/Brasil/Paran $\%$ C3\%A $1 /$ Carambe\%C3\%AD/Hist\%C3\%B3ria/Imigra

\%C3\%A7\%C3\%A3o/Os_imigrantes_holandeses/> , acesso em 02/02/2014. Informações históricas sobre a empresa Batavo podem ser encontradas em < http://www.batavo.com.br/>.

$64 \quad$ GARCIA, op. cit. p. 534.

65 Toledo a Pacheco, tel. ${ }^{\circ}$ 97, Buenos Aires, 16 jul. 1924, AHI 208/02/03; Toledo a Pacheco, tel. $n^{\circ}$ 100, Buenos Aires, 17 jul. 1924, AHI 208/02/03; Toledo a Pacheco, tel. nº 101, Buenos Aires, 18 jul. 1924, AHI 208/02/03. 
que o embaixador norte-americano, Edwin Morgan, fosse analista comedido em relação às agitações internas do Brasil. No entanto, de acordo com outros documentos, a imagem de Morgan é diversa. Quando os rebeldes entraram em Mato Grosso, vindos do Paraguai, já em 1925, o embaixador norte-americano acreditou que os revolucionários e a população desse estado - composta por parcela expressiva de gaúchos e seus descendentes - iriam provocar sérias dificuldades ao governo federal, podendo repetir, nessa região, toda série de agitações que havia ocorrido no Rio Grande do Sul. ${ }^{66}$

Meses antes, quando rebeldes tomaram conta de vários quartéis gaúchos, o embaixador norte-americano torceu para que eles separassem essa unidade da federação do restante do país. Segundo o embaixador norte-americano, o surgimento de uma nação na região do Rio Grande do Sul seria benéfico aos interesses econômicos dos Estados Unidos e à região do Cone Sul. Independentes, os gaúchos constituiriam um país com menos problemas econômicos e sociais que o restante do Brasil e de composição étnica mais próxima da europeia ${ }^{67}$.

Para Morgan, o ideal seria o surgimento de uma República que abrangesse os territórios do Rio Grande do Sul e do Uruguai. Em relatório enviado ao Departamento de Estado, o embaixador norte-americano escreveu que a principal vantagem de uma nação nesses moldes seria que "a rivalidade insensata e ciumenta entre Argentina e Brasil seria diminuída"68, garantindo a paz no Cone Sul e resguardando os interesses econômicos dos EUA sobre a região.

Como exemplo da atuação do serviço de inteligência do Exército Brasileiro, pode ser citada a vigilância sobre a movimentação dos rebeldes nas fronteiras do Brasil com seus vizinhos, além da atenção dada pelos militares à atuação dos servidores do Itamaraty que trabalhavam nos consulados brasileiros no exterior. Os dois casos transcritos abaixo são decorrentes do período em que a Coluna Prestes saiu de Foz do Iguaçu, cruzou parte do Paraguai e ingressou em Mato Grosso.

Para conhecimento de V. Ex. transcrevo o telegrama do Tenente Romeu

$66 \quad$ MEIRELLES, op. cit. p. 385-387.

$67 \quad$ MEIRELLES, op. cit. 386.

68 Relatório do embaixador Edwin Morgan, em 29 de novembro de 1924. Rolo 6, fotogramas 443 e 444. National Archives/USA apud MEIRELLES, op. cit. p. 385-387. 
Balster meu agente de informações do Rio Paraná acaba de receber Foz do Iguaçu: "Foz do Iguaçu 9/6 às 12 horas urgente Gal. Rondon Ponta Grossa. a (Conforme meu telegrama último de Posadas tem chegado da zona Mato Grosso Ponta Poran em Encarnación diversos elementos gente de Prestes creio desertores. (...) Em Encarnación pretenderam iludir boa fé nosso Consulado fazendo-se passar por emigrados Mato Grosso. Consegui em tempo reconhecê-los.) - b (Dia 31 próximo findo notei viajarem trem internacional Assunción para Argentina dois passageiros revolucionários de Prestes um negro e um menos 14 anos presumíveis. Autoridades argentinas quando comboio procede Assunción chega território argentino revistam rigorosamente e exigem passaporte. Como esses dois passageiros passaram presumo que existe alguma facilidade fornecimento de passaporte em nosso Consulado Assunción.) (...) e - (General Isidoro continuando Assunción telegrafou Simas Enéas dizendo que dinheiro todo deveria ser entregue a Miguel Costa. (...) Saudações Tte Balster." Essa informação que é verdadeira nos mostra que Assunción e Posadas são centros atuais de onde os chefes rebeldes continuam a incentivar o bando que invadiu os sertões de Mato Grosso. (...) (Rondon a Pacheco, tel. $\mathrm{n}^{\circ}$ 2129, Ponta Grossa, 1925, AHI Lata 46, maço 377)

Rebeldes continuam auxílios vindos da Argentina. A munição que estão empregando é reconhecida daquela origem. Seria para desejar que houvesse mais vigilância nos pontos de acessos desde Bela Vista até Pirahy. Os rebeldes viviam cruzando em livre trânsito em Bela Vista e Pedro Juan Caballero para Concepción desde muito tempo.(...) (Rondon a Pacheco, tel. no 1813, Guarapuava, 1925, AHI Lata 46, maço 377.)

Analisando as informações contidas nos telegramas, percebe-se que o Itamaraty estava informado em relação ao que se passava com os rebeldes. Os dados que chegavam dos consulados, da inteligência das Forças Armadas e de informantes civis, criaram uma base de dados importante para o governo federal. Não se sabia das movimentações revolucionárias com profundidade; essa, inclusive, foi uma das razões pelas quais a Coluna Prestes conseguiu iludir as forças legalistas em diversas oportunidades, ao longo de sua marcha pelo país, mas muitas informações sobre os revolucionários - suas reais condições de combate, seus objetivos de médio prazo e seus estoques de suprimentos - eram conhecidas por Felix Pacheco e Artur Bernardes. ${ }^{69}$

Como exemplo da eficiência na coleta de informações por parte do governo, pode-se citar a previsão de levante revolucionário no Rio Grande do Sul, mais tarde confirmada pela atuação de Prestes, Siqueira Campos e Juarez Távora. Há

69 Toledo a Pacheco, tel., $\mathrm{n}^{\circ}$ 152, 22 set. 1924, Buenos Aires, AHI, 208/02/03; Toledo a Pacheco, tel., $n^{\circ}$ 164, 25 set. 1924, Buenos Aires, AHI, 208/02/03; Toledo a Pacheco, tel., $n^{\circ}$ 166, 27 set. 1924, Buenos Aires, AHI, 208/02/03; Toledo a Pacheco, tel., n' 173, 30 set. 1924, Buenos Aires, AHI, 208/02/03; Toledo a Pacheco, tel., no 179, 03 out. 1924, Buenos Aires, AHI, 208/02/03. 
destaque para o cônsul de Posadas, que parecia estar a par de várias movimentações revolucionárias: ${ }^{70}$

Dei aviso ao Presidente Borges de Medeiros desse plano dos revoltosos, que iniciarão a seção, invadindo súbita e simultaneamente o Rio Grande, por municípios de Palmeiras, São Luiz, Santo Ângelo, Bagé e Sant'Anna. João Francisco espera aviso de Tavora para vir a Posadas e seguir ao encontro de Zecca Netto e Leonel Rocha. Respeitosamente, (A) Paulo Demodoro. Cônsul. (Toledo a Pacheco, tel., $n^{\circ}$ 203, 14 out. 1924, Buenos Aires, AHI, 208/03/02.)

Uma das maneiras encontradas pelo governo federal para obter quantidade expressiva de dados a respeito dos rebeldes foi o pagamento de informantes, conforme se depreende do seguinte telegrama de 27 de maio de 1925:

Apurar melhor denúncia Mendes dizendo-lhe não teremos dúvida pagar-lhe os 3.500 pesos pedidos, mas depois que ele nos forneça as provas das informações que deve possuir. (Pacheco a Toledo, tel., $n^{\circ}$ 82, RJ, 27 mai. 1925, AHI, 208/02/03)

Pela documentação pesquisada, nota-se a existência de significativo número de "despesas extraordinárias" geradas pela Embaixada brasileira em Buenos Aires e pelos consulados do Brasil em Posadas, Paso de los Libres, São Tomé e Alvear, durante o período em que a Coluna Prestes marchou pelo país. Além do atendimento a necessidades urgentes de famílias brasileiras que imigraram em busca de segurança ${ }^{71}$, do reabastecimento de tropas federais e do financiamento de operações militares próximas às fronteiras ${ }^{72}$, o pagamento de particulares por informações vinculadas às atividades rebeldes foi um dos principais sorvedouros das "despesas extraordinárias", sendo consideráveis as somas de recursos liberados

70 Toledo a Pacheco, tel., $\mathrm{n}^{\circ}$ 142, 16 set. 1924, Buenos Aires, AHI, 208/02/03; Toledo a Pacheco, tel., $n^{\circ}$ 179, 03 out. 1924, Buenos Aires, AHI, 208/02/03; Toledo a Pacheco, tel., $n^{\circ}$ 187, 06 out. 1924, Buenos Aires, AHI, 208/02/03; Toledo a Pacheco, tel., n 193, 08 out. 1924, Buenos Aires, AHI, 208/02/03; Toledo a Pacheco, tel., no 199, 10 out. 1924, Buenos Aires, AHI, 208/02/03; Toledo a Pacheco, tel., $n^{\circ} 215,23$ out. 1924, Buenos Aires, AHI, 208/02/03.

71 Toledo a Pacheco, tel., $\mathrm{n}^{\circ}$ 140, Buenos Aires, 16 set. 1924, AHI, 208/02/03; Toledo a Pacheco, tel., $n^{\circ}$ 143, Buenos Aires, 17 set. 1924, AHI, 208/02/03; Toledo a Pacheco, tel., $n^{\circ} 195$, Buenos Aires, 9 out. 1924, AHI, 208/02/03.

72 Pacheco a Toledo, tel., $n^{\circ}$ 65, RJ, 2 nov. 1924, AHI, 208/02/03; Pacheco a Toledo, tel., $n^{\circ} 61$, 20 mar. 1925, RJ, AHI, 208/03/01; Pacheco a Toledo, tel., nº 80, s/d., 1925, RJ, AHI, 208/03/01; Pacheco a Toledo, tel., nº 91, 2. jul, 1925, RJ, AHI, 208/03/01. 
aos postos da região platina para essa finalidade. ${ }^{73}$

Dessa maneira, percebe-se que o uso do aparato burocrático do Itamaraty não ficou restrito à amenizar os efeitos negativos que a Coluna Prestes gerou na imagem internacional do Brasil ou à responder às reclamações internacionais decorrentes dos prejuízos impostos a outras nações. O Governo de Artur Bernardes usou todos os recursos de que dispunha para debelar o movimento subversivo, sendo a rede de postos do Ministério das Relações Exteriores algo importante juntamente com o serviço de inteligência das Forças Armadas e o próprio Ministério da Guerra. O telegrama 1813, enviado pelo Marechal Rondo a Félix Pacheco, demonstra como a cooperação entre esses órgãos do Executivo ocorreu de maneira estreita, vinculando as ações externas do país aos desdobramentos internos.

\section{Considerações Finais}

De tudo exposto, percebe-se que a influência dos revolucionários da Coluna Prestes sobre a atuação externa do Brasil foi significativa entre julho de 1924 e março de 1927. O combate aos movimentos sediciosos do período, a busca por neutralizar as notícias que eram direcionadas ao exterior e a tentativa de cooperação com os países da vizinhança foram constantes.

Com o levante dos membros da Coluna Prestes, as relações com os países vizinhos ganharam importância para o Brasil. O uso do Ministério das Relações Exteriores como instrumento de repressão foi importante estratégia do governo brasileiro no combate aos rebeldes. O pagamento por informações vinculadas aos revolucionários e a atuação dos cônsules junto às alfândegas do Brasil e dos outros países da região platina demonstram como o Itamaraty tentou cercar a atuação dos membros da Coluna. ${ }^{74}$ Ademais, o trabalho em conjunto entre o Itamaraty e o

73 AHI, 208/02/03; AHI, 208/02/04; AHI, 208/02/05; AHI, 208/02/06; AHI, 208/03/01; AHI, 208/03/02.

74 Os telegramas Toledo a Pacheco, tel. $\mathrm{n}^{\circ}$ 173, Buenos Aires, 16 abr., 1925, AHI, 208/02/04 e Toledo a Pacheco, tel. $\mathrm{n}^{\circ}$ 192, Buenos Aires, 24 abr., 1925, AHI, 208/02/04, demonstram que o governo federal previu a possibilidade de os rebeldes, acuados no oeste do Paraná, abrirem caminho pelo Paraguai, para atingir o Mato Grosso. Como Rondon foi surpreendido por essa manobra, abre-se espaço para indagações a respeito de como os dados levantados pelo Itamaraty eram utilizados pelo Ministério da Guerra e vice-versa, já que ambos os órgão trabalharam em 
Ministério da Guerra pode ter ajudado os comandantes militares que combateram a Coluna Prestes a melhor conhecer a situação dos revolucionários. Ressalte-se, no entanto, que o conhecimento dessas informações pode ter sido importante, mas não foi decisivo para as operações do governo, já que as tropas legalistas não conseguiram derrotar os rebeldes.

Certo é que nos anos de 1927 e 1928, a vigilância dos postos brasileiros sobre as atividades dos rebeldes nos Estados platinos continuou ${ }^{75}$, demonstrando, assim, a existência e continuidade da implementação da "diplomacia antirrevolução das oligarquias", denominada por Eugênio Vargas Garcia. ${ }^{76}$

\section{Fontes}

\section{Fontes primárias}

\section{MENSAGENS PRESIDENCIAIS}

BRASIL. Mensagem Presidencial: 1917 a 1931. Disponível em < http://www.crl.edu/pt-br/brazil/presidential >. Acesso em 15 de novembro de 2010.

\section{RELATÓRIOS MINISTERIAIS}

BRASIL. Ministério das Relações Exteriores. Relatório apresentado ao Presidente da República pelo ministro de Estado das Relações Exteriores. Rio de Janeiro: Imprensa Nacional, 1917-1931. Disponível em $<$ http://www.crl.edu/ptbr/brazil/ministerial/relaçoes_exteriores >. Acesso em 15 de novembro de 2010.

\section{ARQUIVO HISTÓRICO DO ITAMARATY}

Escritório Regional do Ministério das Relações Exteriores no Rio de Janeiro

Correspondências:

- Missão diplomática brasileira em Buenos Aires

Telegramas Recebidos: 1924 (208/2/3), 1925-1926 (208/2/4), 1927 (208/2/5), 1928-1929 (208/2/6).

Telegramas Expedidos: 1921-1926 (208/3/1), 1927-1929 (208/2/6).

- Missão diplomática brasileira em Montevidéu

estreita cooperação no combate aos revolucionários.

75 AHI 208/02/06.

76 Alves a Pacheco, tel. $n^{\circ}$ 201, Buenos Aires, out., 1926, AHI, 208/02/04; Alves a Pacheco, tel. $\mathrm{n}^{\circ}$ 204, Buenos Aires, 6 out., 1926, AHI, 208/02/04; GARCIA op. cit. p. 491. 
Ofícios: $1922(223 / 3 / 1)$

- Missão diplomática brasileira em Assunção

Telegramas Recebidos: 1917-1926 (202/2/1)

- Outros documentos relacionados, separados por organização temática:

Lata 46, maço 377

Lata 183, maço 3039

Lata 471 , maço 7203

Lata 478 , maço 7453

Lata 518 , maço 8427

\section{Documentários}

O Velho: A História de Luiz Carlos Prestes. Direção: Toni VENTURA, 105 minutos. Rio de Janeiro. 1997.

\section{Referências Bibliográficas:}

BREDA DOS SANTOS, Norma. "Diplomacia e fiasco. Repensando a participação brasileira na Liga das Nações: elementos para uma nova interpretação". Rev. bras. polit. int. [online], vol.46, n.2, pp. 87-112, 2003 . Disponível em <http://www.scielo.br/pdf/rbpi/v46n2/v46n2a04.pdf>. Acesso em 05 de Jan. de 2014. BUENO, Clodoaldo. Política externa da Primeira República: os anos de apogeu (1902 a 1918). São Paulo: Paz e Terra, 2003.

CARONE, Edgard. A República Velha - instituições e classes sociais. $2^{\mathrm{a}}$ ed. São Paulo: Rio de Janeiro: DIFEL, 1972.

CARONE, Edgard. A Primeira República: 1889-1930. $2^{\mathrm{a}}$ ed. São Paulo: DIFEL, 1974a.

CARONE, Edgard. A República Velha - evolução política. $2^{\mathrm{a}}$ ed. São Paulo: Rio de Janeiro: DIFEL, 1974b.

CARONE, Edgard. O Tenentismo - Acontecimentos, Personagens, Programas. Rio de Janeiro: DIFEL, 1975.

CARVALHO, José Murilo. Forças armadas e política no Brasil. Rio de Janeiro: Jorge Zahar, 2005.

CARVALHO, José Murilo. Cidadania no Brasil: o longo caminho. $8^{a}$ ed. Rio de Janeiro: Civilização Brasileira, 2006.

CERVO, Amado Luiz e BUENO, Clodoaldo. História da Política Exterior do Brasil. Brasília: Editora Universidade de Brasília, 1994.

CURVO, Luiz Márcio Ambrósio. Jovens, tenentes e rebeldes: a liderança da Coluna Miguel Costa - Prestes. 2005. 139f. Dissertação (Mestrado em História) Departamento de História do Instituto Ciências Humanas da Universidade de Brasília, Brasília.

DRUMMOND, José Augusto. A coluna Prestes: rebeldes errantes. São Paulo: Brasiliense, 1999.

FAUSTO, Boris. História do Brasil. 13ª Ed. São Paulo: EDUSP, 2008. 
GARCIA, Eugênio Vargas. O Brasil e a Liga das Nações (1919-1926): vencer ou não perder. Porto Alegre/Brasília: Editora da Universidade (UFRGS) / FUNAG (Fundação Alexandre de Gusmão), 2000.

GARCIA, Eugênio Vargas. A Diplomacia dos Armamentos em Santiago: o Brasil e a Conferência Interamericana de 1923. Revista Brasileira de História. vol. 46, n. 23, p. 173-200, 2003.

GARCIA, Eugênio Vargas. Entre a América e a Europa: A política externa brasileira na década de 20. Brasília: Editora Universidade de Brasília / FUNAG (Fundação Alexandre de Gusmão), 2006.

IGLESIAS, Francisco. Trajetória política do Brasil: 1500-1964. São Paulo: Companhia das Letras, 1993.

JANOTTI, Maria de Lourdes Monaco. Sociedade e política na Primeira República. São Paulo: Atual, 1999.

LANDUCCI, Ítalo. Cenas e episódios da revolução de 1924 e da coluna Prestes. $2^{\mathrm{a}}$ Ed. São Paulo, Brasiliense, 1952.

LEAL, Vitor Nunes. Coronelismo, enxada e voto: o município e o regime representativo no Brasil. 3.ed. Rio de Janeiro: Nova Fronteira, 1997.

LINHARES, Maria Yedda (org). História geral do Brasil. 9a Ed. Rio de Janeiro: Elsevier, 1990.

MACAULAY, Neill. A coluna Prestes. $2^{\mathrm{a}}$ Ed. São Paulo: Difel, 1977.

MCCANN, Frank D. Soldados da pátria. A história do Exército Brasileiro 1889/1937. Rio de Janeiro: Cia das Letras, 2007.

MEIRELLES, Domingos. As noites das grandes fogueiras: uma história da Coluna Prestes. Rio de Janeiro: Record, 1997.

MOREIRA LIMA, Lourenço. A coluna Prestes. Marchas e combates. São Paulo. Editora Alfa Ômega. 1979.

PARADISO, José. Um lugar no mundo: a Argentina e a busca de identidade internacional. Rio de Janeiro: Civilização Brasileira, 2005.

PRESTES, Anita Leocádia. A coluna Prestes. Rio de Janeiro: Paz e Terra, 1997.

RAPOPORT, Mario (org.). Historia econômica, política y social de la Argentina. (1880-2000). $2^{\mathrm{a}}$ Ed. Buenos Aires: Ediciones Macchi, 2003.

SODRÉ, Nelson Werneck. A coluna Prestes; análise e depoimentos. Rio de Janeiro: Editora Civilização Brasileira, 1978.

SODRÉ, Nelson Werneck. A história militar do Brasil. Rio de Janeiro: Editora Civilização Brasileira, 1979.

TÁVORA, Juarez. À guisa de depoimento sobre a Revolução Brasileira de 1924. v. 3. São Paulo: O Combate, 1928. 